\title{
On the Miserable Female's Fate from A Thousand Splendid Suns
}

\author{
Shengai $\mathrm{Li}^{1,}$ a , Tingting $\mathrm{Liu}^{2, \mathrm{~b}}$ \\ ${ }^{1}$ College of Foreign Languages, Jilin Agricultural University, Changchun 130118, China \\ ${ }^{2}$ College of Foreign Languages, Jilin Agricultural University, Changchun 130118, China \\ Asara6012@sina.com, b1714967175@qq.com
}

\begin{abstract}
Khaled Hosseini is an Afghan-American writer whose works are deeply and richly rooted in the culture of Afghanistan. His second novel A Thousand Splendid Suns is set in Afghan wars, which reveals almost a half-century of miseries and sufferings faced Afghan women. This thesis aims to interpret the miserable female's fate from A Thousand Splendid Suns, which reveals the miserable fate of Afghan women in the social unrest by analyzing the heroines placed in a dilemma, and draws people's attention to raise their consciousness and meditate on the miserable fate of Afghan women through a series of analyzing .
\end{abstract}

Keywords: A Thousand Splendid Suns, Khaled Hosseini,miserable female fate.

\section{Introduction}

As we all know, Afghanistan is a Islamic country which is integrated with politics and religion. Unfortunately, under the strict patriarchy society, they were confined to the families, and deprived of the rights participating in social affairs. Therefore the miserable female's fate is becoming the time brand. For the Afghan women, they will never be the master of their fate. A Thousand Splendid Suns unfolds miserable fate of women through the political turmoil before our eyes. As for the marriage, Afghan women, such Mariam and Laila, play a part of tool to reproduce a new generation and can not gain happiness. During the Taliban-government period, some Islamic doctrine was distorted, the position of Afghan women was downgraded perceptibly, and their aspiration for freedom and equality was seriously subdued[1].

\section{Literature Review}

\subsection{An Introduction to Khaled Hosseini and his works}

Khaled Hosseini was born on March 4, 1965 in Kabul, the capital of Afghanistan. In his childhood, Hosseini's father worked for the Afghan Foreign Ministry as a diplomat while his mother was a local high school teacher who taught Farsi and history. In summary, he was brought up in a literate environment with loving from his family. Meanwhile, he expanded his horizon through reading the classical Persian poetry at the age of five. Because of his father's appointment, his family moved to Tehran, which is the capital and largest city of Ira. After that they returned to Kabul in the year of 1973 with historic importance, when the Republic of Afghanistan was established. Also it is the last year for Afghan to maintain the steadiness of state power and safeguard social stability.

During the invasion from the Soviet army and a bloody communist coup, Hosseini terminated his happy childhood in Afghanistan. His family made a decision to search for political asylum in the United States. Therefore, they settled in San Jose, California in September 1980. He was admitted to Santa Clara University in which he obtained a medical degree in 1988.

After college, Hosseini decided to become a physician and enrolled at the University of California - San Diego's School of Medicine in which he completed his master degree in 1993. Hosseini completed his medical residency at the well-respected Cedars-Sinai hospital in Los Angeles and was a practicing internist. 
Hosseini began to writing his first novel The Kite Runner and published in 2003. This novel became an international bestseller which is sold more than 12 million copies worldwide. Hosseini's dedication to his homeland Afghanistan can be seen not only in his novels but also in his actual deeds. He serves as a goodwill ambassador for United Nation High Commissioner for Refugees.

The Kite Runner(2003) is a story of young boy, Amir, trying to build a closer relationship with his father and copy the memories of unforgettable events in his childhood. Also, this novel has been made into a film of the same name released in December, 2007. "A day is a miniature of eternity." is from The Kite Runner which is one of my favorite quotations. The third novel, In 2003 And the Mountains Echoed published has show important changes made by Hosseini in both the content and the style, therefore appears to be different from his previous works. And the Mountains Echoed keeps a watchful eye on relationships between siblings or sibling-like partnership. It is a collection of nine short stories told from the perspectives of different characters.

\subsection{Background and Theme of A Thousand Splendid Suns}

A Thousand Splendid Suns takes its title from a poem about Kabul by Saib-e-Tabrizi, a 17th-century Persian poet. This poem is wrote after a visit to the city which left him deeply impressed and goes like this:"Every street of Kabul is enthralling to the eye. Through the bazaars, caravans of Egypt pass. One could not count the moons that shimmer on her roofs. And the thousand splendid suns that hide behind her walls." It is translated by Professor Josephine Davis in Persian. "a thousand splendid suns", which is occur from the end of this poem, is fairly suitable to express the theme of this novel[2].

A Thousand Splendid Suns spans a long period of time: from prior to Soviet invasion to the reign of Taliban to the post-Taliban rebuilding[3], which tells a heartrending story against the backdrop of Afghanistan warfare and reveals almost a half-century of miserable female fate in Afghanistan. A Thousand Splendid Suns, which is published in May 2007,concerns on life in Kabul, especially as seen through the eyes of two women in Afghanistan, Mariam and Laila. They have different generation and live intersect for a while.

Through the narration of the lives of two protagonist, Hosseini implies the miserable female fate in Afghanistan, which is filled with oppression and sadness.

\subsection{Previous Studies on A Thousand Splendid Suns}

Sun Quanfang, an English language and literature master who is from Dongbei Normal University discusses A Thousand Splendid Suns through Aesthetic of Reception. The conclusion is given on how the author brings up the reader's imagination through the response-inviting structure in order to blend them into the text for understanding and how the reader concreties this process through reading activities, together with the reaction between the implied reader and the actual reader to reveal the reasons for its wide popularity[4].

The Minneapolis Star Tribune comments that in A Thousand Splendid Suns, Hosseini tells a story about his native land from two female perspective. The rise and fall of the Afghanistan is not strange for a smattering of international readers. But through the rending of this novel, all of this shock us in a new way. It forces us to think that if destined to face the bleak life, what we should do[5].

"Searing epic of Afghanistan in turmoil. His tale is a powerful, harrowing depiction of Afghanistan, but also a lyrical evocation of the lives and enduring hopes of its resilient characters.", Publishers Weekly said.

\section{The Miserable Fate of Mariam and Laila}

\subsection{The Embodiment of Misery}

The heroines in the novel A Thousand Splendid Suns bear the negative effects of different experiences.

Under the oppression of patriarchal society, Mariam is forced to marry 48-year-old shoemaker called Rasheed from Kabul, which happens after her mother commits suicide. But unfortunately, Mariam is in hot water where the phenomenon of domestic violence always happens. It is because she 
is a person with great endurance facing fists and maltreatment from her husband. There had been six months more cycles of hopes raised then dashed, each loss, each collapse, each trip to the doctor more crushing for Mariam than the last. The seven abortions had ceased to hold any hope or illusion. Every time after abortion, the resentment and alienation from Jalil becomes more aggravated. An increasing number of domestic violence she suffered let them drifting away. In this case, Mariam can only be careful to do everything. She was afraid of her own insignificant fault to detonate his "time bomb".

After Laila experienced her family tragedies, although she is able to survive. Her mind is wandering and murmuring about something. The destruction of the war and the death of her family caused great physical and mental trauma for her. The wound may heal, but the trauma of the heart is hard to mend.

\subsection{Characters of Heroines}

Like Nana’s saying, “Like a compass needle that points north, a man's accusing finger always finds a woman."Mariam is an obedient housewife who is suffered servitude by patriarchal society. She longed for the love from her father to gain happiness. After marrying with Rasheed, the unhappy marriage bring her serious consequences, such as domestic violence. Meanwhile, she is a brave person in order to choose to bear all of the blame. For Laila's happiness and her own relief, she ended up Rasheed's life with a shovel.

However, Laila, possessing natural beauty, smartness and a good education, was born in an intellectuals family in Kabul, where she spends her happy time in her childhood and teenage period. During the war, her family got shattered because of losing her brother and the deaths of her parents. She was forced to marry with a shoemaker because Laial is rescued by Rasheed. Meanwhile she is a determined person. When hearing the news that her childhood sweetheart Tariq will come back, she was even determined to escape.

\section{The Causal Analysis of The Misery \\ 4.1 Family Background}

Maraim is an illegitimate daughter of a wealthy businessman Jalil and a housekeeper Nana. When she was born, she was labeled as "halami" . This is the reason why she was ignored. In the fact, her father is as timid as a hare and vainglorious. Nana hated men because of her failed marriage. Her mother told Mariam that men is not good people, men is as same as "Like a compass needle that points north, a man's accusing finger always finds a woman.” It is obvious that Mariam is in a state of anxiety because of Nana's negative ideas. Undoubtedly, her mother is a chief criminal to form Mariam's weak personality. Or maybe you can say she is one of the reasons of her miserable fate.

Laila, another heroine of this novel, is born to a family in Kabul, who is a beautiful and lively girls. And her father is an elegant and eloquent person.Compared with Mariam's family, her childhood was full of sweet memories. But when the news about the deaths of the two brothers at the battlefront, her mother could not stand it and had a mental breakdown. So she had to bear the responsibility of the family.

Hence in the family, for Mariam, the lack of love from her father and her mother's educational style cause she was negative to face everything. Different families have brought up their different personalities.

\subsection{A Victim of the Strict Patriarchy Society}

In Afghanistan, there is one of the few countries in the world to retain the characteristics of patriarchy. So Patriarchy leaves double brands on people's spirit and soul. Rasheed is one of the representatives of the patriarchal society. Patriarchy and the unshakable status of the family let him have supreme superiority. Thus it is for Mariam that violence and indifference make painful to this marriage. Eventually, many times of abortions led to loss procreation without care and love. However, Rasheed wants to marry Mariam because he needs a woman to satisfy his requirements at any time.

Even such a background, Laila did not escape the disaster. Her mother did not attach importance to education, looking down on her husband's elegant. One day, if Laila's mother picked her up from school, she should have protected laila from the insult of a naughty boy. Also Laila thinks that her mother pays attention on her two brothers. During the wars, her two brothers didn't return with 
victory, which made her mother grieved deeply. The decadent conception of her mother makes Laila lose the only all-enduring and selfless love from mother.

\subsection{Traditional Customs' Cruelty}

Afghanistan is a polygamous country. Meanwhile, Afghan had reminded loyal to Islam. The law of marriage in principle specifies monogamy. If such special circumstances happens, it will allow polygamy.If there is not such the system of marriage existing in Afghanistan, Jalil's mind won't be tained by the evil thoughts, and Laila won't marry with him. Thus Mariam and Laila won't be trapped in the cage of this marriage. Also Afghan women are powerless to change and escape from this unhappy marriage.

Afghan women yearn and desire for freedom hiding behind the burqa and veil.The burqa and veil imposed on women is more like the barricade impregnable for Afghan women' communication with the outside world. The burqa and veil constraint the mind of people indirectly, which plant the seeds of sorrow in the hearts of Mariam and Laila.

\subsection{Scars of Wars}

After the disintegration of the Soviet Union, the regime of Najibullah lost the external support. Thus it made war imminent. It is in this political background that Laila unfortunately suffered the misfortune of her family. The threat of wars overhung the country, which also bring death and famine. Meanwhile, those who most long for peace pour their lives on war

Taliban originates from the movement of fundamentalism in Kandahar, which is the second largest city in Afghanistan. Most of the members are students who come from Madrasah in Afghan refugees. The country was severely suppressed by Islam when Taliban was in power.n this situation, Laila was force to separate herself from her daughter Aziza in order to ensure her safety. If it were not for Taliban, she would not let her be separated from her daughter. Taliban is such an organization, which makes Afghan women suffer from war at loose ends.

\section{Conclusions}

Khaled Hosseini is a gifted writer who has been a dark horse in recent American literature. As a contemporary writer, Hosseini pays attention to ordinary people's life and destiny. The social background in Afghanistan serves as important creation source. Therefore, readers are moved by the vividness and genuineness in his works. To conclusion, this thesis intends to interpret the novel A Thousand splendid Suns from the miserable female's fate.

\section{Acknowledgments}

When I dotted the last punctuation of this thesis, I am indebted to many people not only during the process of working on this thesis but also in the years of learning.My supervisor is frequently patient with me, never harsh but she continues offering encouragement which has been and will always be a motive to push me forward in the study of literature.

\section{References}

[1] Liu Yang, The Redemption of an Unfortunate Spirit- A Feminist Approach to A Thousand Splendid Suns.(2011)

[2] Information on http://www.GX.xinhua.net.com, A Thousand Splendid Suns: Hosseini's new book tells the power of love again.(2007)

[3] Chen Penghua, A Feminist Reading of A Thousand Splendid Suns(2013)

[4] Sun Quanfang, An Interaction between Implied Reader and Actual Reader-An Analysis of A Thousand Splendid Suns through Aesthetics of Reception(2009)

[5] Khaled Hosseini, A Thousand Splendid Suns, Penguin Group(USA)Inc(2008) 